Acta Technologica Agriculturae 3

Nitra, Slovaca Universitas Agriculturae Nitriae, 2019, pp. 75-79

\title{
MONITORING OF GAS PRODUCTION DURING THE BIOWASTE COMPOSTING
}

\author{
Peter HLINKA ${ }^{1 *}$, Ingrid KARANDUŠOVSKÁ ${ }^{2}$, Štefan MIHINA ${ }^{2}$ \\ 'Local Union of Ponitrie Villages for Separation and Management of Waste, Slovakia \\ ${ }^{2}$ Slovak University of Agriculture in Nitra, Slovakia
}

\begin{abstract}
The aim of this paper was to monitor the production and composition of gases from the biowaste landfill in terms of the utilized composting process technology. Processing technology of biowaste in the reference sample V1 was without modification; process optimization technology - material homogenization by overturning and irrigation - was used for the second sample V2. Gas measurements (methane, carbon dioxide, ammonia, nitrous oxide) were conducted during the first and sixth weeks after their establishing. At the same time, samples were taken for laboratory determination of the dry matter content of examined materials, $\mathrm{pH}$ and $\mathrm{C} / \mathrm{N}$ ratio. It has been statistically proved that there was a significantly higher gas production in $\mathrm{V} 2$, which was overturned and irrigated, than in V1. The measured $\mathrm{CO}_{2}$ values were 2.5 times higher in V2 in comparison to V1. The mean $\mathrm{CH}_{4}$ production in the stack V1 was $96.35 \mathrm{mg} \cdot \mathrm{m}^{-3}$ and $235.9 \mathrm{mg} \cdot \mathrm{m}^{-3}$ in the stack V2, which is 2.5 times more. Due to overturning and irrigation of composted material in the stack V2, the decomposition of microorganisms was faster, which also affected the amount of released gases.
\end{abstract}

Keywords: biological waste; municipal waste; landfill gases; composting

The issue of waste management is one of the biggest environmental challenges in Slovakia. Generally, municipal waste in Slovakia contains a large amount of waste suitable for sorting and recovery. It includes e.g. plastics, paper, glass, metals and biodegradable waste. Landfilling each of these components is economically disadvantageous and represents a major health risk (Hrabčák, 2013). Biodegradable waste (BDW) accounts for $40 \%$ of the mixed waste in average. It might seem that biodegradable waste does not represent a risk to the environment. However, BDW needs the optimal conditions for its decomposition, recovery and utilization of nutrients in the form of compost (Demirbas, 2011). Landfills do not provide these conditions and biowaste is compressed together with other kinds of waste in the landfill. Thereby, decomposition occurs without air and causes putrescence process. The harmful gases (such as methane) are released into the air during rotting and groundwater is polluted by landfill leachates. Numerous waste management activities are carried out in the exterior or in front of operating halls and thus they become the source of surface or fugitive emissions (Hroncová and Ladomerský, 2017). Gaseous emissions in the air represent probably the largest share of negative environmental impact of municipal waste landfilling. These are mainly methane $\left(\mathrm{CH}_{4}\right)$, nitrogen oxides, hydrogen sulphide and volatile non-methane organic compounds (Hrabčák, 2017). Biowaste can be composted either as municipal waste (35 to $70 \%$ of its total weight deposited in the Slovak Republic at landfills is currently represented by biowaste) or incinerated in waste incinerators. Biowaste composting is considered by experts to be one of the most efficient means of $\mathrm{CO}_{2}$ production reduction in human activities and thus also a method exploitable in fight against global warming. Due to the implementation of the European Union landfill directive to divert the biodegradable waste fraction from the municipal solid waste stream (CEC, 1999), composting has received widened interest as a means of addressing the current waste management challenges. During composting, fugitive emissions primarily depend on the compost feedstock, as well as on process and operating conditions (Amlinger et al., 2005; Amlinger et al., 2008). In addition to the composting operation, the $\mathrm{C} / \mathrm{N}$ ratio, texture of the input material, humidity and temperature conditions are the essential parameters influencing the greenhouse gas production (He et al., 2001; Eklind et al., 2007; Amlinger et al., 2008). Globally, biogas production for energy use is considered to be active step towards climate protection and sustainable life technology, in which waste from animal production, livestock excrements, residues of various crops (Kažimírová et al., 2018) can be used as starting materials.

The aim of the experiment was to monitor the production and composition of landfill gases and investigate the impact of the used bio-waste recovery process on landfill gas production.

Hypotheses:

$\mathrm{HO}$ : There is no significant difference between gas production at stacks $\mathrm{V} 1$ and $\mathrm{V} 2$ at the start of the biodegradation process (week 1 ).

Contact address: Peter Hlinka, Local Union of Ponitrie Villages for Separation and Management of Waste, Slovakia, e-mail: peter.hlinka19@gmail.com 
H1: There is no significant difference between gas production at stacks V1 and V2 on week 6 of the biodegradation process.

$\mathrm{H} 2$ : There are no significant differences in gas production between week 1 and 6 of the biodegradation process at each stack.

\section{Material and methods}

The composting plant for biodegradable waste, where the experiment was carried out, is located in the cadastral area of Výčapy-Opatovce at an altitude of $155 \mathrm{~m}$. This village belongs to the area of lowland climate with slight temperature inversion. Total landfill capacity is 5,000 tonnes per year of biodegradable waste for composting. Two stacks of biowaste (V1 and V2) at the same time and with the same volume $\left(10 \mathrm{~m}^{3}\right)$ were needed to set up the experiment with implementation of a different technological process for composting waste at each pile. In terms of technology of biowaste processing, reference sample V1 was untreated and the second sample V2 was optimized by homogenization of material by overturning and irrigation. Each stack was equipped with a shaft for exhaustion of landfill gases. During the experiment, the temperature inside each pile was monitored daily in order to determine the need to overturn and irrigate the waste in V2. Gas production measurements (methane, carbon dioxide, ammonia, nitrous oxide) at each stack were conducted during the first and sixth weeks after their establishing. Simultaneously, samples from V1 and V2 were taken for laboratory determination of the content of dry matter, $\mathrm{pH}$ and $\mathrm{C} / \mathrm{N}$ ratio of the materials examined. Considering the processing of collected data, programme Statistica 10 was utilized for statistical analysis of significant differences. Pfeuffer GT 1 needle thermometer was used to measure compost temperature, allowing measurements at a depth of up to $1.5 \mathrm{~m}$, as well as on the surface. Determination of compost moisture, $\mathrm{pH}$ and $\mathrm{C} / \mathrm{N}$ nutrient ratio was performed at a certified laboratory. These physical and chemical properties are important for comparison of two biowaste recovery technologies, by which the decomposition rate and the correct recovery method can be assumed for further use. Multigas Monitor
1312 gas analyser, together with the Multipoint Sampler 1309 sampler were used to measure emissions.

Measuring points:

V1 - measuring in the shaft fitted in a stack without modification of technological process;

V2 - measuring in the shaft fitted in a stack with optimization of technological processes.

\section{Results and discussion}

Table 1 shows the results of a 24-hour gas production measurement in both V1 and V2 stacks monitored on week 1 after sample creation. During the first week, mean $\mathrm{CO}_{2}$ content reached values of $46,335.58 \mathrm{mg} \cdot \mathrm{m}^{-3}$ in $\mathrm{V} 1$, and $5,2551.29 \mathrm{mg} \cdot \mathrm{m}^{-3}$ in $\mathrm{V} 2$. Mean $\mathrm{N}_{2} \mathrm{O}$ content, production of which slightly decreased in both piles during the measurement, reached value of $55.69 \mathrm{mg} \cdot \mathrm{m}^{-3}$ in $\mathrm{V} 1$, and $64.00 \mathrm{mg} \cdot \mathrm{m}^{-3}$ in $\mathrm{V} 2$. Recorded mean $\mathrm{NH}_{3}$ content was $471.19 \mathrm{mg} \cdot \mathrm{m}^{-3}$ in $\mathrm{V} 1$, and $436.93 \mathrm{mg} \cdot \mathrm{m}^{-3}$ in V2. With moderate fluctuations, mean $\mathrm{CH}_{4}$ production reached $862.19 \mathrm{mg} \cdot \mathrm{m}^{-3}$ and $750.63 \mathrm{mg} \cdot \mathrm{m}^{-3}$ in V1 and V2, respectively. During week 1, production of landfill gases at monitored bio-waste piles $\mathrm{V} 1$ and V2 did not differ significantly (Table 1) despite the fact that they contained identical material and volume of each stack and gas contents were measured immediately three days after creation of samples. Both samples were without any intervention at that time. From the material samples taken during the week 1 , the same values of $\mathrm{pH}(6.13)$ and moisture (68.42\%) were found in both V1 and V2 stacks (Table 3).

The gas production results obtained in the 24-hour measurement during the week 6 after establishing of V1 and V2 are shown in Table 2. It was statistically proven that there was recorded significantly higher gas production in V2, which was overturned and irrigated, than in V1 (Table 2). The $\mathrm{CO}_{2}$ content was 2.5 times higher and the $\mathrm{N}_{2} \mathrm{O}$ content was almost 3 times higher in V2 in comparison to V1. Mean $\mathrm{NH}_{3}$ content in $\mathrm{V} 1$ was $12.74 \mathrm{mg} \cdot \mathrm{m}^{-3}$; mean $\mathrm{NH}_{3}$ content in V2 was $58.35 \mathrm{mg} \cdot \mathrm{m}^{-3}$, making it almost 5 times higher. Mean $\mathrm{CH}_{4}$ production was $96.35 \mathrm{mg} \cdot \mathrm{m}^{-3}$ in $\mathrm{V} 1$ and $235.9 \mathrm{mg} \cdot \mathrm{m}^{-3}$ in V2 -2.5 times higher. The amount of gases released depends on microbial activity; therefore, it can be concluded that microorganisms decomposed the composting material in

Table 1 Gas production at measurement points V1, V2 - week $1\left(\mathrm{mg} \cdot \mathrm{m}^{-3}\right)$

\begin{tabular}{|c|c|c|c|c|}
\hline Gas & Measurement points - stack & Number of meas. & Average \pm stand. dev. & $P$-value \\
\hline \multirow{2}{*}{$\mathrm{CO}_{2}$} & V1 & 466 & $46,335.58 \pm 3,380.66^{\mathrm{a}}$ & \multirow{2}{*}{0.06} \\
\hline & V2 & 466 & $52,551.29 \pm 3,000.82^{\mathrm{a}}$ & \\
\hline \multirow{2}{*}{$\mathrm{N}_{2} \mathrm{O}$} & V1 & 466 & $55.69 \pm 10.68^{\mathrm{a}}$ & \multirow{2}{*}{0.08} \\
\hline & V2 & 466 & $64.00 \pm 11.13^{\mathrm{a}}$ & \\
\hline \multirow{2}{*}{$\mathrm{NH}_{3}$} & $\mathrm{~V} 1$ & 466 & $471.19 \pm 30.55^{\mathrm{a}}$ & \multirow{2}{*}{0.08} \\
\hline & V2 & 466 & $436.93 \pm 28.62^{\mathrm{a}}$ & \\
\hline \multirow{2}{*}{$\mathrm{CH}_{4}$} & V1 & 466 & $862.19 \pm 48.27^{\mathrm{a}}$ & \multirow{2}{*}{0.06} \\
\hline & V2 & 466 & $750.63 \pm 38.40^{\mathrm{a}}$ & \\
\hline
\end{tabular}

${ }^{a}$ the same upper indices indicate - there is no significant difference in gas production between $\mathrm{V} 1$ and $\mathrm{V} 2$ at $p<0.05$ 
Table 2 Gas production at measurement points V1, V2 - week $6\left(\mathrm{mg} \cdot \mathrm{m}^{-3}\right)$

\begin{tabular}{|c|c|c|c|c|}
\hline Gast & Measurement point - stack & Number of meas. & Average \pm stand. dev. & $P$-value \\
\hline \multirow{2}{*}{$\mathrm{CO}_{2}$} & V1 & 462 & $6,481.49 \pm 802.72^{\mathrm{a}}$ & \multirow{2}{*}{0.00009} \\
\hline & V2 & 462 & $16,135.51 \pm 1,852.36^{b}$ & \\
\hline \multirow{2}{*}{$\mathrm{N}_{2} \mathrm{O}$} & V1 & 462 & $4.45 \pm 0.50^{\mathrm{a}}$ & \multirow{2}{*}{0.00008} \\
\hline & V2 & 462 & $13.00 \pm 1.57^{b}$ & \\
\hline \multirow{2}{*}{$\mathrm{NH}_{3}$} & V1 & 462 & $12.74 \pm 1.10^{\mathrm{a}}$ & \multirow{2}{*}{0.00008} \\
\hline & V2 & 462 & $58.35 \pm 5.45^{b}$ & \\
\hline \multirow{2}{*}{$\mathrm{CH}_{4}$} & V1 & 462 & $96.35 \pm 15.33^{\mathrm{a}}$ & \multirow{2}{*}{0.00009} \\
\hline & V2 & 462 & $235.90 \pm 35.00^{b}$ & \\
\hline
\end{tabular}

${ }^{\mathrm{ab}}$ different upper indices indicate significant difference in gas production in V1 and V2 at $p<0.05$

Table 3 Analysis of material samples from stacks V1 and V2

\begin{tabular}{|l||c|c|c|c|c|c|}
\hline \multirow{2}{*}{$\begin{array}{l}\text { Time of } \\
\text { sampling }\end{array}$} & $\mathbf{p H}$ & moisture (\%) & $\mathbf{C : N}$ & $\mathbf{p H}$ & moisture (\%) & C: $\mathbf{N}$ \\
\hline \hline Week 1 & 6.13 & 68.42 & $9.12: 1$ & 6.13 & 68.42 & $9.12: 1$ \\
\hline Week 6 & 7.29 & 27.45 & $23.59: 1$ & 8.22 & 46.9 & $12.7: 1$ \\
\hline
\end{tabular}

V2 more rapidly thanks to overturning and irrigation. As reported by other authors (Sundberg and Jonsson, 2007), it is possible to shorten the time needed for production of a stable compost product and thus to increase the efficiency of composting plants by increasing the aeration and adding water to compensate for drying. The same results were achieved by Hrad et al. (2014), who reported that emissions were higher during the overturning and thus the frequency of shovelling appears to be a key factor in regulation of emissions during biowaste composting.

There were also observed different $\mathrm{pH}$ values in V1 and V2 - namely 7.29 and 8.22 , respectively - different moisture contents in material samples taken from V1 (27.45\%) and V2 (46.9\%) on week 6 (Table 3).

From the initial values of the gas concentrations measured at week 1 , the gas concentrations at week 6 in each stack decreased to significantly

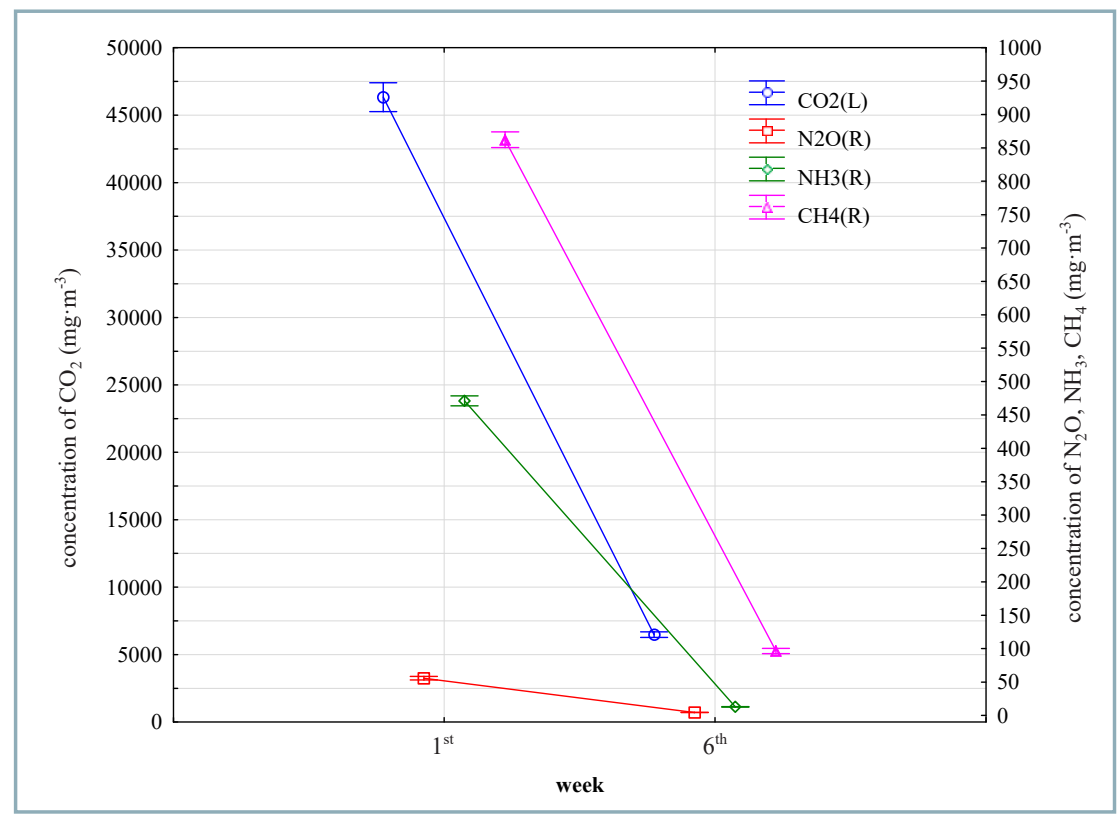

Fig. 1 Comparison of gas production on weeks 1 and 6 - stack V1 $\left(\mathrm{mg} \cdot \mathrm{m}^{-3}\right)$ Wilks lambda $=0.00760, F(4,124)=4,050.2, p=0.0000$

lower levels (Figs. 1 and 2). However, in $\mathrm{V} 2$, this decrease was smaller since the decomposition process taking place inside the stack was supported by aeration as a result of overturning, making the composting an aerobic process. However, aeration caused the compost drying. Therefore, irrigating was needed in order to increase the temperature, allowing thus the faster degradation of composted material, since moisture facilitates the movement of microorganisms and serves as a medium for chemical reactions.

The maximum $\mathrm{CO}_{2}$ concentrations observed during the week 1 correspond to the maximum temperatures recorded during the first days of composting; as the temperatures gradually dropped, the amount of $\mathrm{CO}_{2}$ produced also decreased. These results are consistent with the findings of several other authors (Plíva et al., 2006; Jiang, 2011), who reported that the amount of released $\mathrm{CO}_{2}$ decreases with compost maturation time; furthermore, they observed that material temperature, $\mathrm{pH}$ and $\mathrm{C} / \mathrm{N}$ nutrient ratio have also significant impacts on $\mathrm{CO}_{2}$ compost production. Fig. 3 shows the course of temperature during the entire process, indicating the time of overturning and irrigating the stack V2. The temperature rose rapidly at the start of the experiment, a maximum temperature of $70{ }^{\circ} \mathrm{C}$ was 


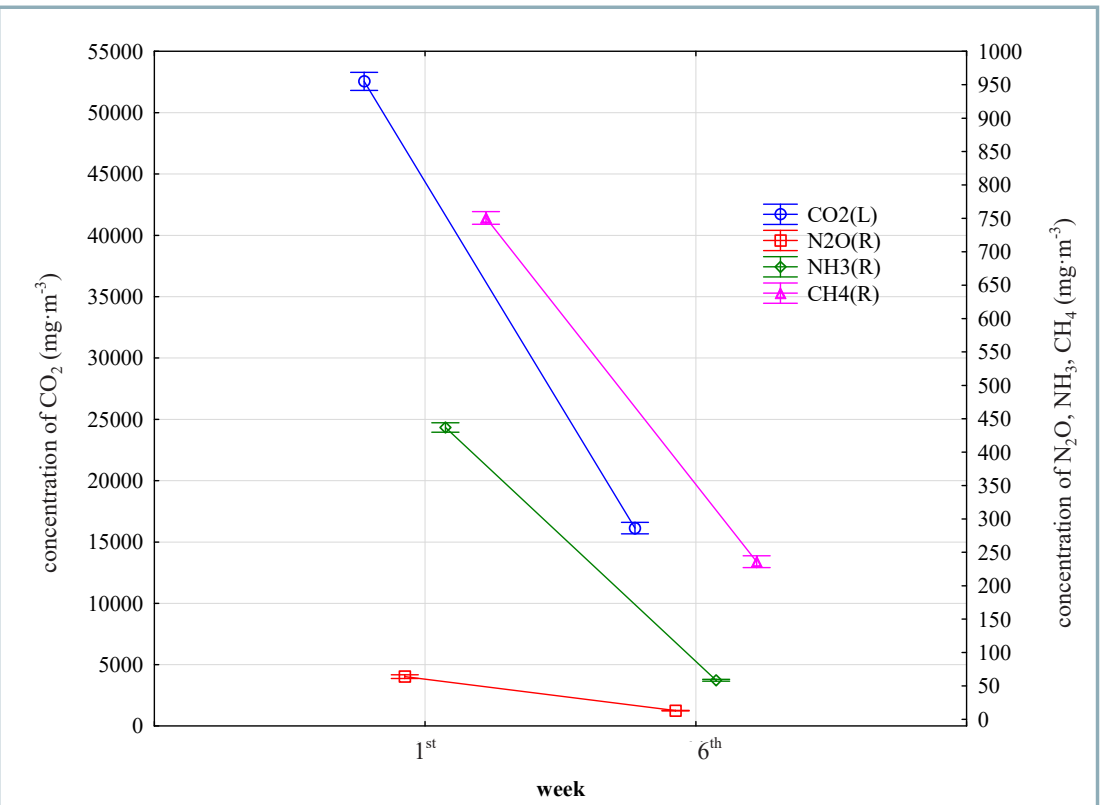

Fig. 2 Comparison of gas production on weeks 1 and $6-\operatorname{stack~V2~}\left(\mathrm{mg} \cdot \mathrm{m}^{-3}\right)$ Wilks lambda $=0.00822, \mathrm{~F}(4,124)=3,738.4, p=0.0000$

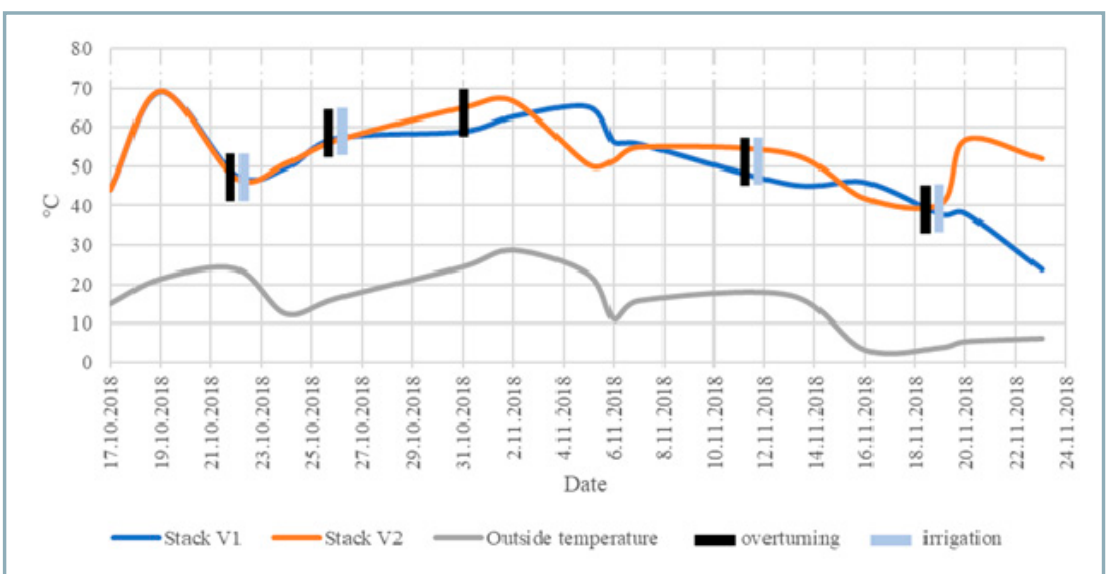

Fig. 3 Temperature profile of samples in V1 and V2

observed on the third day, causing a short mesophilic phase followed by a slight decrease in temperature to $45^{\circ} \mathrm{C}$. After adjusting by means of overturning and irrigating, the temperature rose close to $70{ }^{\circ} \mathrm{C}$. However, the temperature inside the pile is also affected by the external temperature, which varied from 7 to $27^{\circ} \mathrm{C}$. Hellmann et al. (1997) and Osada et al. (2010) observed similar results in a system of composting in rows. These temperature variations were caused by the degradation of partially decomposed materials that were transferred from anaerobic to aerobic areas (Jiang, 2011).

Considering the measurement results recorded during the week 6 , it is obvious that the production of the monitored gases was higher in V2 compared to V1. During the first week, the $\mathrm{C} / \mathrm{N}$ ratio of samples $\mathrm{V} 1$ and $\mathrm{V} 2$ was equal, $9.12: 1$. During the week 6 , the $\mathrm{C} / \mathrm{N}$ ratio of samples $\mathrm{V} 1$ and $\mathrm{V} 2$ was $23.59: 1$ and $12.7: 1$, respectively. Table 3 shows that the observed gas concentrations in sample V2 were higher. The $\mathrm{C} / \mathrm{N}$ ratio is an important factor in controlling microbiological metabolism (Godwin et al., 2017). As reported by Amlinger et al. (2008), the amount of $\mathrm{CO}_{2}$ released also depends on the $\mathrm{C} / \mathrm{N}$ ratio. $\mathrm{CO}_{2}$ emissions are lower when the $\mathrm{C} / \mathrm{N}$ ratio of processed raw materials is higher. However, a low $\mathrm{C} / \mathrm{N}$ ratio is responsible for higher $\mathrm{NH}_{3}$ emissions, especially at good aeration and high compost temperatures. Therefore, a $\mathrm{C} / \mathrm{N}$ ratio $>25$ will help to minimize $\mathrm{NH}_{3}$ and $\mathrm{N}_{2} \mathrm{O}$ emissions. However, a $\mathrm{C} / \mathrm{N}$ ratio $>35$ may result in the available nitrogen pool limiting the proper decomposition and humification process (Amlinger, 2008). Jiang (2011) states in his study that a lower $\mathrm{C} / \mathrm{N}$ ratio resulted in a higher production of methane emissions by reduction in the air spaces. High aeration rate can reduce the $\mathrm{CH}_{4}$ emissions, whereas the emissions of $\mathrm{N}_{2} \mathrm{O}$ and $\mathrm{NH}_{3}$ increase. As the author further states, the moisture content can affect the methane and ammonia emissions during the composting period. However, he does not consider the moisture impacts significant.

For the purpose of reference, monitoring report of gas measurement emitted from the body of municipal solid waste mixed with biodegradable waste using degassing shafts is provided (Potyš, 2018). The author observed the average $\mathrm{CO}_{2}$ content of $15.6 \mathrm{vol}$ \%, which is $28,6681.2 \mathrm{mg} \cdot \mathrm{m}^{-3}$, and average $\mathrm{CH}_{4}$ content of $21.4 \mathrm{vol}$. \%, which is $142,257.6 \mathrm{mg} \cdot \mathrm{m}^{-3}$. Although these data are not comparable with experiment presented, because the amounts and compositions of gaseous emissions depend on moisture, temperature, etc., by application of anaerobic decomposition stage, it can be assumed that the municipal waste mixed with biowaste produces higher amounts of harmful gases than biodegradable waste composted separately. However, this will be the subject of further investigation.

\section{Conclusion}

Gaseous emissions (especially methane) from composting can be a significant source of anthropogenic greenhouse gases emissions and air pollution. An experiment was conducted to estimate the effects of aeration by means of overturning and moisture content on the gas production during composting. A 24-hour measurement method was used and the gas production was compared in two open stacks located at two waste piles with different processing technology of composted material. Results showed that the production of all monitored gases was the highest at the beginning of composting process and the amount 
of gases gradually decreased during the process. By comparing the two technological compost treatments, it has been shown that the higher gas production and faster decomposition of microorganisms occur when compost material is overturned and irrigated, resulting in reduction of time necessary for achieving of a stable compost product and increasing compost efficiency. On the basis of the evaluated data in the first week, the $\mathrm{HO}$ hypothesis can be accepted, since the production of landfill gases in the monitored biowaste stacks V1 and V2 did not differ significantly at the beginning of the process. Hypothesis $\mathrm{H} 1$ proved to be false, because statistical analysis of significant differences has shown that the gas production in V2, which was overturned and irrigated, was significantly higher than in V1 in the sixth week. Furthermore, this is also true for $\mathrm{H} 2$ hypothesis, since by analysing significant differences in gas amounts produced during the first and sixth weeks, it was statistically proven that landfill gas production differs significantly at the significance level $\alpha=0.05$. Directive of the European Parliament and Council 2008/98/EC on waste, as well as Council Directive 1999/31/EC on the landfill of waste, clearly prioritize the use of biodegradable waste according to the waste hierarchy - material recovery before energy recovery and waste disposal (Jensen et al., 2017). Consequently, all biowaste that is not contaminated with foreign substances and other unsuitable ingredients should be used primary for compost production.

\section{Acknowledgments}

This work was done in the frame of a research project funded from the European Union under the title ITEPAg "Application of information technologies to increase the environmental and economic efficiency of production agro-system", TMS 26220220014

\section{References}

AMLINGER, F. - PEYR, S. - CUHLS, C. 2008. Green house gas emissions from composting and mechanical biological treatment. In Waste Management \& Research, vol. 26, no. 1, pp. 47-60.

AMLINGER, F. - PEYR, S. - MÜSKEN, J. 2005. State of the art of Composting. Environment and Water Management and Compost Development \& Consulting, Directive_202 Compost, Germany: $103 \mathrm{p}$.

CEC, Council of the European Communities, 1999. Council Directive 1999/31/EC on the landfill of waste. Official Journal of the European Communities no. L 182/1-19. https://eur-lex.europa.eu/ legal-content/EN/TXT/?uri=celex\%3A31999L0031

DEMIRBAS, A. 2011. Waste management, waste resource facilities and waste conversion processes. In Energy Conversion and Management, vol. 52, no. 2, pp. 1280-1287.

EKLIND, Y. - SUNDBERG, C. - SMARS, S. - STEGER, K. - SUNDH, I. - KIRCHMANN, H. - JÖNSSON, H. 2007. Carbon turnover and ammonia emissions during composting of biowaste at different temperatures. In Journal of Environmental Quality, vol. 36, no. 5, pp. $1512-1520$.
GODWIN, C. M. - WHITAKER, E. A. - COTNER, J. B. 2017. Growth rate and resource imbalance interactively control biomass stoichiometry and elemental quotas of aquatic bacteria. In Ecology, vol. 98, no. 3, pp. 820-829.

HE, Y. - INAMORI, Y. - MIZUOCHI, M. - KONG, H. - IWAMI, N. - SUN, T. 2001. Nitrous oxide emissions from aerated composting of organic waste. In Environmental Science and Technology, vol. 35, no. 11, pp. 2347-2351.

HELLMANN, B. - ZELLES, L. - PALOJÄRVI, A. - BAI, QY. 1997. Emission of climate-relevant trace gases and succession of microbial communities during open-windrow composting. In Applied and Environmental Microbiology, vol. 63, no. 3, pp. 1011-1018.

HRABČÁK, M. 2013. Landfill gas - threat or benefit? In. Waste Management, 2013/07. https://www.odpady-portal.sk/ Dokument/101742/skladkovy-plyn-hrozba-ci-uzitok.aspx

HRABČÁK, M. 2017. Quantification of fugitive emissions from landfills. http://www.odpadoveforum.cz/TVIP2017/ program st.html

HRAD, M. - BINNER, E. - PIRINGER, P. - HUBER-HUMER, M. 2014. Quantification of methane emissions from full-scale open windrow composting of biowaste using an inverse dispersion technique. In Waste Management, vol. 34, no. 12, 2014, pp. 2445-2453.

HRONCOVÁ, E. - LADOMERSKÝ, J. 2017. Air pollution by aerosols from selected area and fugitive waste management sources. In Waste Forum 2017. http://www.odpadoveforum.cz/TVIP2017/ program st.html

JENSEN, M. B. - MØLLER, J. - MØNSTER, J. - SCHEUTZ, C. 2017. Quantification of greenhouse gas emissions from a biological waste treatment facility. In Waste Management, vol. 67, pp. 375-384.

JIANG, T. - SCHUCHARDT, F. - LI, G. - GUO, R. - ZHAO, Y. 2011. Effect of $\mathrm{C} / \mathrm{N}$ ratio, aeration rate and moisture content on ammonia and greenhouse gas emission during the composting. In Journal of Environmental Sciences, vol. 23, no. 10, pp. 1754-1760.

KAŽIMÍROVÁ, V. - GADUŠ, J. - GIERTL, T. 2018. Verification of suitability of substrate composition for production and quality of biogas. In Acta Technologica Agriculturae, vol. 21, no. 3, pp. 118-121.

OSADA, T. - SOMMER, S. G. - DAHL, P. - ROM, H. B. 2010. Gaseous emission and changes in nutrient composition during deep litter composting. In Acta Agriculturae Scandinavica, Soil \& Plant Science, vol. 51, no. 3, pp. 137-142.

PLÍVA, P. - BANOUT, J. - HABART, J. - JELÍNEK, A. - KOLLÁROVÁ, M. - ROY, A. - TOMANOVÁ, D. 2006. Establishment, Process and Management of Composting Process. $1^{\text {st }}$ edition, Prague: Research Institute of Agricultural Technology, 65 pp. ISBN 80-86884-11-2.

POTYŠ, Z. 2018. Monitoring of Process, Formation and Composition of Landfill Gases. Žilina: Hydrogeoservis, 14 pp.

SUNDBERG, C. - JONSSON, H. 2007. Higher pH and faster decomposition in biowaste composting by increased aeration. In Waste Management, vol. 28, no. 3, pp. 518-26. 